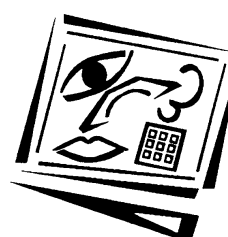

\title{
Incorporating online discussion in face to face classroom learning: A new blended learning approach
}

\author{
Wenli Chen and Chee-Kit Looi \\ Nanyang Technological University
}

\begin{abstract}
This paper discusses an innovative blended learning strategy which incorporates online discussion in both in-class face to face, and off-classroom settings. Online discussion in a face to face class is compared with its two counterparts, off-class online discussion as well as in-class, face to face oral discussion, to examine the advantages and disadvantages of the proposed strategy. By integrating online discussion into the flow of the classroom, learners are given dedicated time to foster a habit of critical thinking, reflection and articulating these online, which can subsequently seed further in-class oral discussions, and off-class online discussions. It is found that inclass, online discussion can provide a wider spectrum of discussion perspectives, equalise participation in discussion, and promote cognitive thinking skills and in depth information processing. However, the lack of face to face interactions and the need for sufficient time to do online postings pose challenges in implementing online discussion for face to face classroom learning.
\end{abstract}

\section{Introduction}

The widespread adoption of learning technologies has led to increased levels of integration of computer mediated communication (CMC) into traditional face to face learning. The benefits of incorporating online elements in learning and education have been multifold, such as the capacity to increase student engagement, to enhance critical analysis and reflection, and to promote the social construction of knowledge as well as collaborative thinking (Dehler \& Parras-Hernandez, 1998; Ruberg, Moore, \& Taylor, 1996; Warschauer, 1997). The approach of combining face to face instruction with computer mediated instruction is called blended learning (Graham, 2005). As an alternative to traditional face to face instruction, blended learning has been adopted by more and more educators and learners in recent years, and the trend towards blended learning systems will increase (Graham, 2005). 
Considerable literature has been accumulated on blended learning. Researchers from multidisciplinary fields try to determine the effective ways and practices of incorporating online elements, such as how to pair the best options of online learning with the best features of face to face learning, and how much and what type of online learning is appropriate? The vast majority of existing research has focused on exploring the use of online learning in an off-classroom setting as a supplement to face to face instruction. It would therefore be natural to ask whether extending the application of online learning to an in-class, face to face setting would be a useful new teaching and learning strategy, or just an impractical idea. There is, however, hardly any related practice or research documented in the literature. This study presents a new look at blended learning by implementing online discussion in both in and off-classroom settings in a professional development course for teachers, and evaluates the advantages and drawbacks of such a practice.

\section{Literature review}

\section{Online discussion in learning}

The research literature on online discussion in learning has proliferated recently with many authors documenting the advantages of online discussion in teaching and learning. One of the widely cited advantages of online discussion is its increased flexibility due to removing time and space restrictions of the typical classroom setting (Curtis \& Lawson, 2001; Harasim, Hiltz, Teles \& Turoff, 1995; Henri, 1992). The asynchronous capabilities of online discussion allow learners to have more time to think "deeply" before giving their opinions (Moore, 2002). The interactive nature of online discussion helps promote discussion among learners, creating a forum for the creation of knowledge (Gay, Sturgill, Martin \& Huttenlocher, 1999). Through online discussion, education and learning can be transformed from a one way instructional approach to a highly interactive approach to learning (Henri, 1992; Vrasidas \& McIssac, 1999; Warschauer, 1997). Online discussion can facilitate collaborative learning, when learners are actively engaged in sharing information and perspectives through interaction with other learners (Harasim, 1989).

Additionally, online discussion provides a permanent record of one's thoughts for later students' reflection and debate, by automatically saving the messages posted in the discussions. Online discussion technology can also track the frequency and times of each student logging onto the class (Hara, Bonk \& Angeli, 1998). Research findings show that online discussion allows students to see different perspectives, which can help to foster new meaning construction (Ruberg et al., 1996) and encourages participants to put their thoughts into writing in a way that others can understand, 
promoting self reflective dialogue and dialogue with others (Valacich, Dennis \& Comolly, 1994); and it has the potential to expose students to a broader range of views than face to face talk, and hence enable them to develop more complex perspectives on a topic (Prain \& Lyons, 2000).

Despite these clear advantages, there are also disadvantages with online discussion in education and learning. For example, the removal of time constraints can impose overloads on both instructors and students with ceaseless opportunities to learn and work. This could result in not only an inefficient communication process, but also the possibility of misinterpretations of meaning. The lack of social cues is another disadvantage of CMC. When social cues are absent, participants cannot use gesture, voice tone and facial expression and they have to guess what their audience is feeling (Hara, Bonk \& Angeli, 1998). The lack of social cues may foster anti-normative and uninhibited behaviors (Sproull \& Kiesler, 1991) and hinder the forming of community bonding.

\section{Blended learning}

Blended learning systems combine face to face instruction with computer mediated instruction (Graham, 2005). Many researchers share the view that the most common reason for adopting blended learning is that it combines "the best of both worlds". Beyond this general statement, Graham, Allen and Ure (2003) found that people chose blended learning for three reasons: (1) improved pedagogy, (2) increased access or flexibility, and (3) increased cost effectiveness. Some researchers have argued that blended learning approaches increase the level of active learning strategies, peer to peer learning strategies, and learner centered strategies used (Collis, Bruijstens \& Veen, 2003; Morgan, 2002). It provides a balance between flexible learning options and the high touch, human interactive experience (e.g., Dziuban, Hartmann, Juge, Moskal \& Sorg, 2005; Reynolds \& Greiner, 2005). In addition, blended learning systems provide an opportunity for reaching a large, globally dispersed audience in a short period of time with consistent, semi-personalised content delivery (Bersin \& Associates, 2003).

Future learning systems will be differentiated not based on whether they blend but rather by how they blend (Ross \& Gage, 2005). However, how to create effective blended learning experiences is still a challenge for researchers and practitioners. This challenge is highly context dependent with a practically infinite number of possible solutions (Bonk \& Graham, 2005). Many researchers are still seeking out best practices for how to combine instructional strategies in face to face and CMC environments that exploit the strengths of each environment and minimise their weaknesses (Osguthorpe \& Graham, 2003). 
Although there is extensive research done on blended learning, the focus is invariably on the application of online learning in an off-class, or after class, setting. There is little practice reported or research conducted into online discussions in face to face classroom settings. This study depicts an innovative example of blended learning, using online discussion in a face to face classroom setting among a group of adult learners.

Figure 1 is a $2 \times 2$ matrix representing the communication modes and the different contexts of usage. The blended learning designs reported in the literature fall mostly in the A cell (traditional oral communication in face to face class), and the C cell (CMC off or after class). In this study, we probe into the efficacy of the B cell (CMC in face to face context).

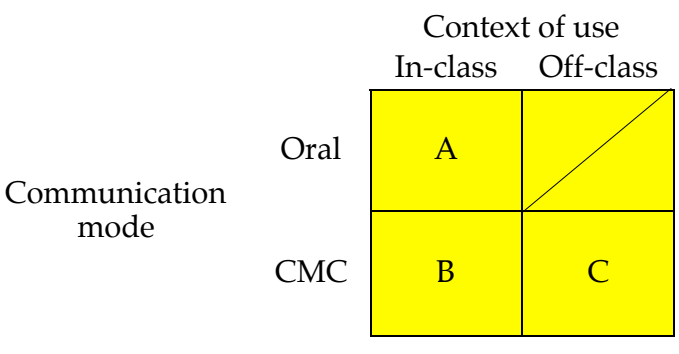

Figure 1: Matrix of different communication modes vs. different contexts of use

\section{Instructional design}

The target group examined in this study consisted of 16 Heads of Departments of Information Technology (IT HoDs) from Singapore schools who attended a professional development course. This course, conducted by National Institute of Education, Singapore, was to help the IT HoDs explore and think about their roles and responsibilities as an IT HoD, through which issues and problems faced could be solved by collaboration and sharing of resources as members of a working community.

Eight face to face sessions of the course were conducted once a week, each lasting 3 hours. Each session focused on one particular issue relevant to the role of IT HoDs, such as IT integration in schools, the Singapore Ministry of Education's Master Plan for IT in Education, engaged and deep learning, technology planning in schools, evaluation of IT plans, and the Classroom of the Future. In the first session of the course, the learners were told that the course incorporated online discussions both in-class and off-class, and that in order to get the best out of the course, they were expected to participate actively in online discussions. Figure 2 shows the teaching and learning cycle of this course. 


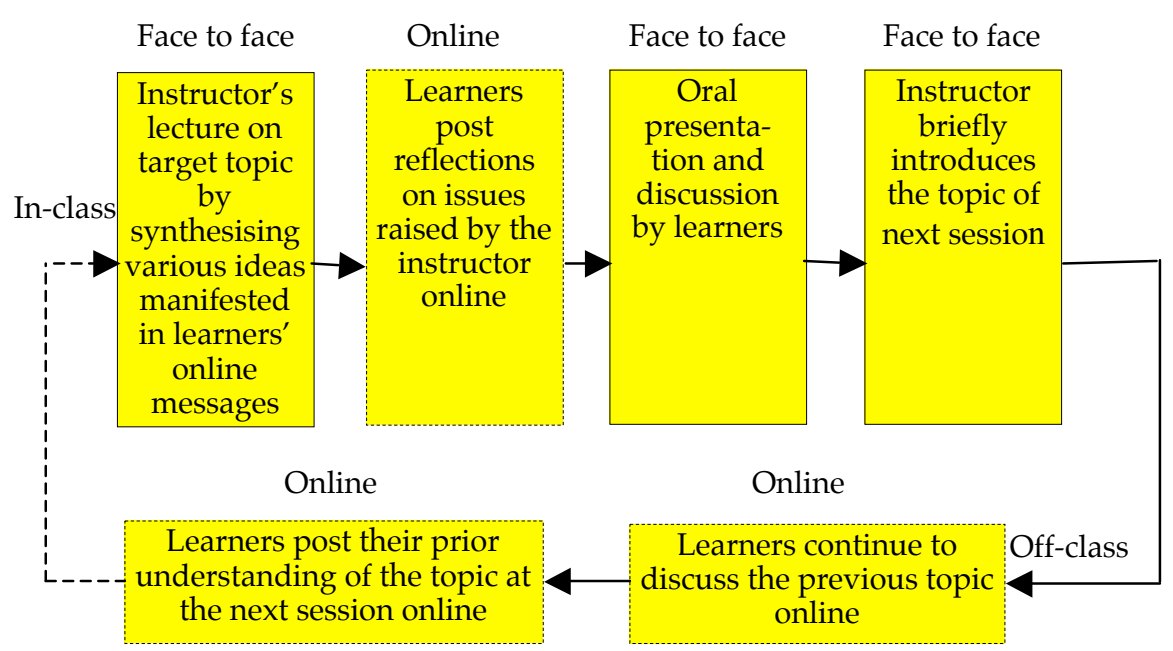

Figure 2: The teaching and learning cycle

This design extends the potential of online discussion into face to face classroom settings. The in-class and off-class online discussions were designed with the following objectives:

1. In-class discussion and off-class discussions complemented each other. The online discussion was planned not just to be an "add on", but to be an integral part of the learning environment. By integrating online discussion into the flow of the classroom, learners are given time to foster a habit of critical thinking, reflection and articulating online, which can subsequently seed further in-class discussions and off-class online discussions.

2. The in-class discussion was task oriented. Typically, the instructor provided some guiding questions in-class to prompt the learners to type their responses and thoughts about the questions during the class.

Learners were required to post their reflections on a particular topic or issue.

3. The discussion was learner centered. The instructor wanted to encourage voluntary and proactive involvement in online discussions instead of imposing on the learners to contribute because they were required to so. The learners were told that the message postings were not graded for summative course assessment.

The learners logged onto a course portal to post their messages using a threaded discussion forum tool. As the course portal is incidental to the purposes of this paper, we will not describe the software environment here. 


\section{Methodology}

This study adopted a triangulation approach to examine several dimensions of incorporating online discussion in-classroom. Three research methods were applied in this study: content analysis to analyse the nature and quality of the online discussions, classroom observations to gather information about the learners' classroom activities and performance which may affect their face to face online discussion behaviour, and in depth interviews to get the learners' perceptions, opinions, and suggestions about the new strategy. These methods complement each other and are used to help sketch a full picture of the participation pattern and effectiveness of the in-class online discussions.

\section{Content analysis}

Content analysis is a technique that is often used to analyse transcripts of computer mediated discussion in educational settings. Nowadays different coding frameworks have been designed to suit particular evaluation purposes and to fit certain education contexts. They reflect a wide variety of approaches and differ in their levels of detail and the type of analysis categories used (De Wever, Schellens, Valcke \& Van Keer, 2005). Some examine critical thinking (e.g., Fahy, 2005; Newman, Webb \& Cochrane, 1995), social, cognitive and teaching presence (e.g., Rouke, Anderson, Garrison \& Archer, 1999; Garrison, Anderson \& Archer, 2001; Anderson, Rourke, Garrison \& Archer, 2001), problem based learning (Oriogun, 2003), others examine knowledge construction (e.g., Gunawardena, Lowe \& Anderson, 1997; Pena-Shaff \& Nicholls, 2004; Weinberger \& Fischer, 2005; Veerman \& Veldhuis-Diermanse, 2001) and the interactional exchange patterns (Fahy, Ally, Crawford \& Cookson et al., 2000).

In this study, Henri's (1992) framework was adapted. It is grounded in a cognitive view of learning, which focuses on the level of knowledge and skills evident in the learners' communications. The framework analyses data in five broad dimensions: participation, social, interaction, cognitive and meta-cognitive aspects. Clulow and Brace-Govan (2001) applied Henri's (1992) model to a graduate course to examine interaction and cognitive skills, and concluded that this framework is a useful tool for teachers who want to know what kind of thinking is going on in their courses. One of the main reasons that Henri's coding framework is employed in this study is that it contains broader dimensions than other coding frameworks so that researchers can examine online discussions more comprehensively.

Henri used idea as a unit of analysis instead of the complete message itself. Hara, Bonk and Angeli (2000) used paragraph as a unit of analysis for the 
same five dimensions as Henri (1992), assuming that each paragraph was a new idea unit, as the learners in their study (college level students) should be able to break down the messages into paragraphs. In online discussions, an "idea" tends to be summarised in a paragraph, as this is how people normally organise written communication. Therefore, the unit of analysis for this study was the paragraph.

The messages were coded by two research assistants. The inter-rater reliability test result using Cohen's kappa (1960) showed that the interrater reliability between the two coders was 1 on the participation dimension, 0.49 on the interactive dimension, 0.44 on the social dimension, 0.50 on the 5 category cognitive dimension, 0.75 in depth of information processing, and 0.41 on the meta-cognitive dimension. With respect to the interpretation of Cohen's kappa, Capozzoli, McSweeney and Sinha (1999) suggest that: “... values greater than 0.75 or so may be taken to represent excellent agreement beyond chance, values below 0.40 or so may be taken to represent poor agreement beyond chance, and values between 0.40 and 0.75 may be taken to represent fair to good agreement beyond chance." (p.6) According to the criteria, the coding on participation and depth of information processing has excellent agreement, and the coding on interactive, social, 5 category cognitive, and the meta-cognitive dimensions has fair to good agreement.

\section{Classroom observations}

Observation is a research method used to examine the object of a study in its natural setting. The researcher sat in the classroom during the eight sessions, recording events, taking notes on the students' face to face discussions, and observing the students' behavior. The researcher was introduced to the learners on the first session of the course and they were told that the researcher would collect data for research purposes.

\section{Survey}

During the last session (week 8) of the course, a questionnaire was administered to all the learners to obtain information about their participation pattern with respect to their in-class and off-class online discussions, and how they perceived these. The questionnaire also asked them about their frequencies of discussion postings, activities they were doing online, reasons for participating in the online discussions, and their attitudes and perceptions about the online discussions.

\section{In depth interviews}

In depth interviews were conducted immediately after the last session of the course. Six learners who had different levels of participation in their 
online discussions were chosen to be interviewed. Each interview lasted 20 to 40 minutes. During the interviews, the learners shared their opinions, evaluations, motivations, experiences and feelings about the face to face course, in-class discussion, and off-class discussion. When examining the advantages and disadvantages of in-class online discussion, we compare it with its two counterparts, off-class discussion as well as in-class, face to face discussion.

\section{Findings}

\section{Learners' online discussion and participation}

This online group was created on January 2006 before the course started. The members included 16 learners and the course instructor. The messages coded in this study were posted during Jan 25 to Mar 20. During this period, one main group and 11 subgroups were created (Table 1). The names of the group are the topic areas.

Table 1: Descriptions of the groups

\begin{tabular}{|c|l|c|c|c|c|}
\hline SN & \multicolumn{1}{|c|}{ Name of the group } & $\begin{array}{c}\text { Time } \\
\text { created }\end{array}$ & Creator & $\begin{array}{c}\text { No. of } \\
\text { messages }\end{array}$ & $\begin{array}{c}\text { No. of } \\
\text { paras }\end{array}$ \\
\hline 1 & Main group & Week 1 & Instructor & 26 & 72 \\
\hline 2 & Self introduction & Week 1 & Instructor & 14 & 14 \\
\hline 3 & Miscellaneous discussions & Week 1 & Instructor & 4 & 4 \\
\hline 4 & Mind maps of engaged learning & Week 1 & Instructor & 31 & 106 \\
\hline 5 & Examples of engaged learning & Week 2 & Instructor & 19 & 91 \\
\hline 6 & Strategies for schools & Week 3 & Instructor & 23 & 93 \\
\hline 7 & Tech planning and BY(i)TES & Week 4 & Instructor & 27 & 147 \\
\hline 8 & Attachment to ETD & Week 4 & Instructor & 21 & 21 \\
\hline 9 & Classroom of the future & Week 5 & Instructor & 46 & 162 \\
\hline 10 & Project B & Week 5 & Learner 2 & 15 & 61 \\
\hline 11 & Community of practice & Week 6 & Instructor & 35 & 82 \\
\hline 12 & Project A & Week 6 & Learner 1 & 10 & 24 \\
\hline
\end{tabular}

The main group, created by the instructors on the first week, was intended for discussions on general issues about this course. Nine subgroups were created by the instructors, 6 of which were directly related to the course content discussion (Mind maps of engaged learning, Examples of engaged learning, Strategies for schools, Tech planning and BY(i)TES, Classroom of the future, and Community of practice). The other three subgroups created by the instructors were not directly related to the course content. The subgroup "Self introduction" was for learners to introduce themselves to each other. Subgroup "Attachment to ETD" was for issues related to the industrial attachment to Educational Technology Division of the Ministry of Education Singapore, which was held in week 8. The two subgroups on Project A and Project B were created by two learners, who were leaders of 
their collaborative projects. They were used to discuss their projects or related issues.

Overall there were 269 messages posted during the above mentioned period, from which 877 analysis units (paragraphs) were identified. Among the messages, $223(83 \%)$ were posted by the learners, 46 were posted by the instructors $(16 \%)$, and the rest $(1 \%)$ were posted by technical staff. On average, each learner posted 14 messages and each instructor posted 11 messages. Among the 269 messages, about half (136) of the messages were posted during face to face lectures and the other half, off-class (133). On average, each message contained 3.2 units; each unit on average consisted of approximately 3 sentences (or 70-80 words). On average, there were 25 messages and 80 units in each subgroup.

During each session, the instructor allocated from 15 minutes to half an hour for learners to post online, and almost every learner did some posting during that time. In the survey, the learners were asked how often they read the online discussions off-class. 10 learners reported that they did so once a week, 3 of them did so 2 or 3 times a week, and one learner did it at least once a day. The learners spent between 5 to 30 minutes with an average of 15 minutes on the online discussion forum each time when they logged on, off-class.

\section{Advantages of face to face class online discussion}

Participation in discussion is equalised in face to face class by online discussion. In this study we compared the number of messages posted by different learners in-class and off-class, which was an indicator of chances the learners got to express themselves. As shown in Figure 3, all learners participated in the online discussion in-class, and the number of postings by each learner was similar. However, differences in the number of postings off-class by different learners were more apparent. One learner posted 29 messages off-class, whilst two learners never posted off-class.

During the face to face class discussion time, when the instructor asked learners to share their ideas, usually between three to five learners spoke in the face to face classes. During the 3-hour session, normally less than 10 learners expressed their ideas to their peers. Each time the oral discussion ended because no more learners would like to share. The possible reason is that some learners were "reticent" to speak in front of others, while some others were inactive in thinking when their peers were sharing.

Take the "Classroom of the future" (COTF) session as an example. Before the learners came to the face to face lecture, the instructor encouraged them to post online messages about their imagination and expectations of COTF, 
and 10 out of the 16 learners did post. During the class, after they visited a physical COTF which was located at the National Institute of Education, the number of postings increased substantially. All 16 learners posted their reflections about on the positive and negative points of COTF, their thoughts on bringing the COTF concepts to their school, and what they will depict in the new COTF if they are in charge. When asked to share their reflections vocally, only 4 learners spoke out their thoughts.

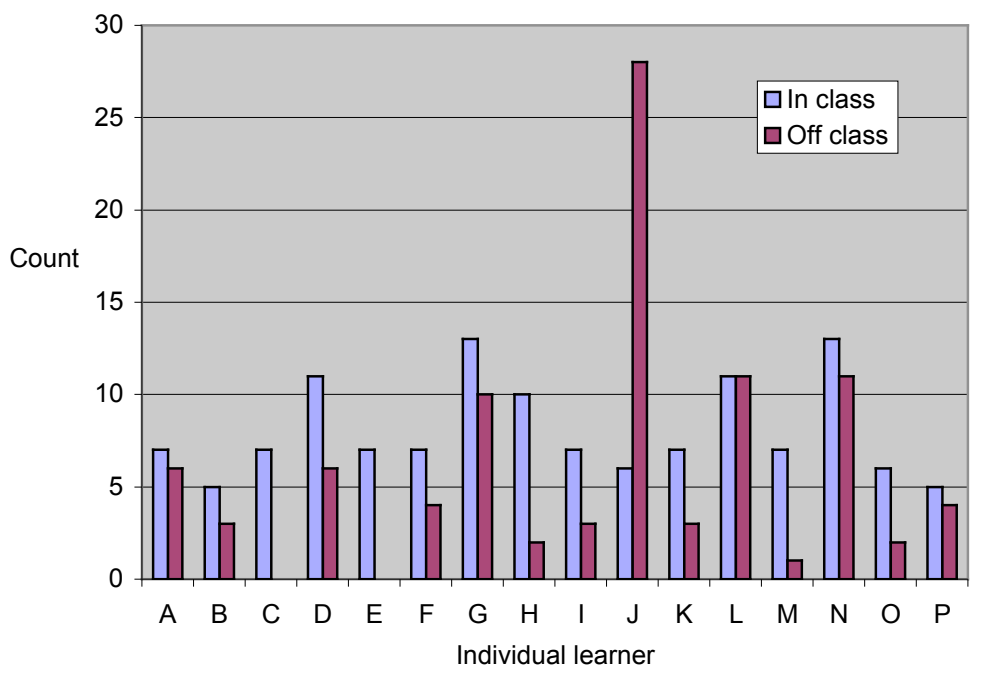

Figure 3: Number of postings by each learner, in-class and off-class

Apparently, in-class online discussions can equalise learners' participation to a great extent, when most of them were task oriented so that learners felt more obliged to post and they knew the instructors would synthesise their ideas later. The equalisation of in-class online discussion may benefit those who are "reticent" to speak in front of others, and push those who are inactive in thinking to think and post more frequently. The equalisation may lie in another aspect that learners are more likely to judge their peers from the knowledge reflected in the postings, instead of other factors which may be linked with their face to face speaking.

Learners engage in extensive writing in online discussion during face to face class. Because of the text intensive nature of online discussion, hybrid courses are often more writing-intensive than their face to face counterparts. For example, discussion responses are generally more thoughtful when written than when given extemporaneously through oral speaking.

In each face to face class, learners were given 15-30 minutes to post their thinking and reflection in the online discussion area. They were also 
encouraged to post even after class. The extensiveness of writing can be measured by the length of messages, which was operationalised by the number of sentences.

An independent sample $t$-test was conducted to compare the length of messages posted in-class and off-class (Table 2). The result showed that the in-class messages have 2.5 more sentences than off-class messages $(t=$ $1.973, p<.05)$. The learners engaged in more extensive writing in-class than off-class.

Table 2: Independent sample $t$-test of length of postings and time of postings $(\mathrm{N}=223)$

\begin{tabular}{|c|c|c|c|c|}
\hline & & $\mathrm{N}$ & Mean & $t$ \\
\hline $\begin{array}{c}\text { Number of } \\
\text { sentences }\end{array}$ & In-class & 129 & 10.64 & \multirow{2}{*}{$1.973^{*}$} \\
\cline { 2 - 4 } & Off-class & 94 & 8.14 & \\
\hline Note: ${ }^{*} p<.05$
\end{tabular}

When analysing the messages in detail, we found that one of the reasons that the in-class messages were lengthier than the off-class messages is that, as the learners were given time by the instructor to write online during class, they were more likely to make full use of the time express their ideas. But after class the learners may not spend as much time writing messages online, compared with in-class. Most of the in-class messages were independent messages that elaborated learners' understandings on a particular concept in as much detail as possible whereas most after-class messages were interactive discussions among learners, with each message not necessarily lengthy, but learners could add another message after getting feedback from others who responded to the thread.

In-class online discussion provides more perspectives upon ideas.

When the in-class online discussion and the in-class oral discussion were examined in detail, it was observed that the online discussion provided more perspectives than oral discussions. For example, during oral discussion, it was very rare that learners had heterogeneous opinions towards certain issues. In one session there was an oral discussion on how the Ministry of Education (MOE) could help schools to do technology planning. When the instructor sought oral opinions from the learners, only four learners shared their opinions, mainly focusing on the workable guide of technology planning, incubator schools as models to follow, and the need for more sharing and communication. However, in online discussions, almost every learner stated their opinions, and the perspectives were expanded to include discussions about financial matters and support for planning by experienced MOE staff. One of the learners, Dennis, in his interview commented, 
You can see the different types of reflections online. And it's really a variety. It's important that we can see or hear everyone's perspective. We need not accept everybody's view, but it's important that we can get a sense.

The heterogeneous perspectives of in-class online discussion may be due to the following two reasons:

1. In oral discussion, learners may be affected by other outspoken ideas into conforming to homogeneity, which may discourage them from expressing their ideas; if a learner feels the others' opinions were shared by many peers, she may be reluctant to share their real feeling due to the "spiral of silence" effect (Neumann, 1984), and if she feels others had already expressed the same or similar ideas as her, then she may not want to use up time to make a similar point. But in online discussion, learners think independently and the thinking will not follow others' ideas blindly.

2. Asian classrooms tend to have a strong didactic educational tradition, in which some students are not inclined to become involved in face to face discussions. In addition, Asian culture does not encourage people to openly challenge others, as such practice is considered impolite and sometimes inappropriate. In online settings, learners may feel more comfortable about posting views or opinions differing from others.

In-class online discussion contains more in depth clarification and inference skills. Scholars have long investigated the connections between writing and thinking (e.g., Vygotsky, 1962): it is through the actual process of writing our thoughts and working them over that we really come to understand. The written record allows for in depth clarification and revision, and encourages self reflection and inference, which are important learning strategies for developing a deeper understanding of concepts. This study has a similar finding, that online discussion, when compared to oral discussion, contains more in depth clarification and inference skills. By integrating online discussion into the flow of the classroom, learners are given dedicated time to foster a habit of critical thinking, reflection and articulating them online. Such online postings can subsequently seed further in-class discussions and off-class online discussions.

In the in depth interview, one of the online discussion participants of the study, Dennis, shared his perception towards online discussion,

I think online discussion will improve the cognitive development. Because when we type, tendency is that they have a bit more time to think through. ... And when you type, you will tend to be more conscious of what you type. It sounds like you have to think twice. 
A Chi-square test was conducted to examine the relationship between the cognitive skills manifested in the postings and time of postings (Table 3). The results indicated that paragraphs posted in-class demonstrated more in depth clarification $(43 \%)$ than those posted off-class $(31 \%)$, and the in-class postings also contains a higher percentage of inference skills $(20 \%)$ than off-class postings $(6 \%)$. The percentage of elementary clarification in paragraphs posted off-class $(40 \%)$ was much higher than for the paragraphs posted in-class $(14 \%)$.

Table 3: Chi-square test of cognitive skills and time of posting $(\mathrm{N}=644)$

\begin{tabular}{|c|c|c|c|c|c|c|}
\hline & \multicolumn{5}{|c|}{ Category of cognitive skills } & \multirow[b]{2}{*}{$\begin{array}{l}\text { Chi } \\
\text { square }\end{array}$} \\
\hline & $\begin{array}{l}\text { Elementary } \\
\text { clarification }\end{array}$ & $\begin{array}{c}\text { In depth } \\
\text { clarification }\end{array}$ & Inference & Judgment & Strategy & \\
\hline \multirow{2}{*}{ In-class } & 68 & 205 & 96 & 51 & 54 & \multirow{4}{*}{$63.977^{*}$} \\
\hline & $14.3 \%$ & $43.2 \%$ & $20.3 \%$ & $10.8 \%$ & $11.4 \%$ & \\
\hline \multirow{2}{*}{ Off-class } & 77 & 59 & 12 & 19 & 23 & \\
\hline & $40.5 \%$ & $31.1 \%$ & $6.3 \%$ & $10.0 \%$ & $12.1 \%$ & \\
\hline
\end{tabular}

Note: ${ }^{* *} p<.01$

For example, the messages posted in-class were mostly responses to the instructor's request to post their reflection on a certain issue, for example, "what does a community of practice mean for you?" or "how to level up your school's IT integration?" These topics need more in depth clarification and inference skills. But many off-class postings especially those beforeclass postings about prior knowledge of a particular concept were more likely to be basic understanding of learners which mainly need elementary clarification. It is noted that the percentage of judgment and strategy is similar for in-class messages and off-class messages. This may be because many after-class postings were complementary explanations of in-class postings, which delineated the practical implications of knowledge discussed in-class.

In-class online discussion contains more in depth information processing.

Information processing is closely related to cognitive skills. In the content analysis, this measure was used to classify the responses into the categories of superficial and in depth processing. Messages classified as evidence of surface level processing involved mostly examples where participants contributed information about extra resources without elaboration. Messages demonstrating deeper levels of processing involved relating new information to their experiences, critically evaluating ideas, and exploring strategies.

A Chi-square test was employed to compare the level of information processing between in-class postings and off-class postings (Table 4). This revealed that that paragraphs posted in-class had $20 \%$ more in depth 
information processing than those posted between classes (Pearson Chisquare $=28.003, p<.01)$.

Table 4: Chi square test of depth of information processing and time of posting $(\mathrm{N}=644)$

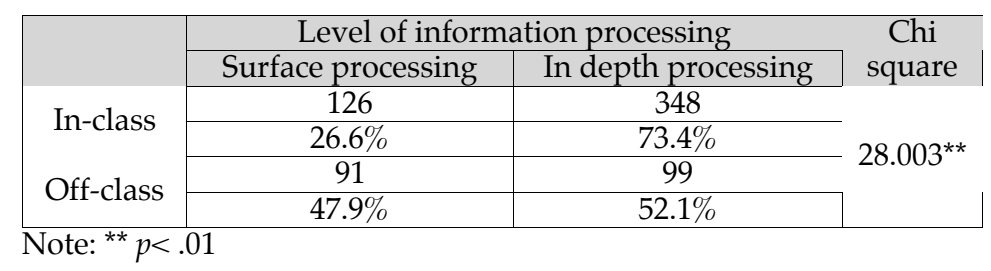

During class, the instructor provided leading questions or tasks for the learners to contribute online postings, and this focus and scaffolding explains the more in-depth processing in-class, compared to between classes. Additionally, interviews with the learners indicated that they felt that the online discussion can be more in depth. As shared by one learner, Gloria:

I think that online discussion will be more in depth than oral discussion. Because we would have thought about it before we typed. After some thinking, when you type it out, the content will be more substantial. But when we talk, it is sometimes quite impulsive.

\section{Disadvantages of face to face class online discussion}

In-class online discussion lacks interaction.

The first disadvantage identified is that in-class online discussion lacks interactions, as compared to both oral discussion and off-class discussion. In the in-class oral discussions, learners and instructors talk face to face and interact actively. However, most of the in-class online postings were independent postings, without replying and commenting on postings from others. A Chi-square test was employed to compare the level of interaction between in-class postings and off-class postings (Table 5). The result showed that in-class postings were less likely to comment or respond to others' posting than off-class postings (Chi-Square $=15.658, p<.01$ ).

The reason why in-class online postings were less interactive than off-class postings is that learners may interact more by oral communication when sitting face to face in the classroom. The lack of interaction is one of the key disadvantages perceived by the learners. As stated by Dennis:

When we are side by side but we cannot talk to one another and we have to talk through the computer, it will reduce the kind of social interaction.

Therefore we must balance the amount of oral discussion and the amount of typing to discuss... I am not comfortable with typing in-class when we 
don't even know each other. Once we know, then we will know how to respond, or to use specifically, the way to respond. That is definitely more useful.

Wilson shared the same feeling about the in-class discussion:

I mean the posting in-class doesn't facilitate that kind of contact. Even when we come to face-to-face, you don't have an opportunity to really get into contact one another in deep understanding discussion. Once people get to know one another, they feel comfortable to post and reply.

Table 5: Chi-square test of level of interaction and time of posting $(\mathrm{N}=223)$

\begin{tabular}{|c|c|c|c|c|}
\hline & \multicolumn{3}{|c|}{ Level of interaction } & \multirow[b]{2}{*}{$\begin{array}{l}\text { Chi } \\
\text { square }\end{array}$} \\
\hline & $\begin{array}{c}\text { Independent } \\
\text { statement }\end{array}$ & $\begin{array}{l}\text { Implicit commentary } \\
\text { and response }\end{array}$ & $\begin{array}{l}\text { Explicit commentary } \\
\text { and response }\end{array}$ & \\
\hline \multirow{2}{*}{ In-class } & 109 & 15 & 5 & \multirow{4}{*}{$15.658^{* *}$} \\
\hline & $84.5 \%$ & $11.6 \%$ & $3.9 \%$ & \\
\hline \multirow{2}{*}{ Off-class } & 63 & 11 & 19 & \\
\hline & $67.7 \%$ & $11.8 \%$ & $20.4 \%$ & \\
\hline
\end{tabular}

Note: ${ }^{* *} p<.01$.

In-class online discussion needs more time and may be inefficient.

Although learners have more time to think during typing, the typing itself takes time. Too much online discussion in-class may slow the progress of the class. In the class, listening is to some extent a compulsory practice for interacting with instructors and peers. It cannot be assumed that every participant in online discussion reads all the messages, although many of them contain more cognitive thinking and in-depth information processing.

\section{Conclusion}

From a new angle, the current study incorporates online discussion within a face to face classroom setting and examines its advantages and disadvantages as compared to off-class online discussion, and oral discussion in a blended learning environment. In this study, the learners engaged in extensive writing in online discussion during the class, when the learners shared their reflections, deeper thinking and experiences, even though participation was not an assessment criterion for the course. Inclass online discussion provided more perspectives as learners were able to think independently and were more willing to share their real feelings, which might be very different from the view held by the majority.

Moreover, with in-class online discussion, participation in discussion was equalised in two aspects: firstly, everybody had an equal chance to participate and fully express his/her ideas, and secondly, learners judged their peers by the knowledge they articulated more than by other factors, 
such as social status, external appearances, accent or charisma. As a result, the class became a more democratic learning environment, and those "reticent" to speak in front of others were encouraged to express themselves, whereas those inactive in thinking were pushed to think and post more frequently. In-class online discussion was also found to contain more cognitive thinking skills, such as in depth clarifications and inferences. Compared to oral discussions, written messages were produced more thoughtfully. The in-class online discussions demonstrated deeper levels of information processing that involved relating new information to the participants' experiences, critically evaluating ideas, and exploring strategies. This implies that in-class online discussion in the context of our study was successful in supporting the learner's cognitive thinking.

Some disadvantages with in-class online discussion were also revealed by the study. Firstly, it lacks interaction, because most of the online postings were task oriented, independent postings without replies and comments on postings by others. Secondly, too much online discussion in-class may slow the progress of the class. Thirdly, in-class online discussion does not assure that every learner will read the online postings, because reading online discussion was not a compulsory practice. This finding is consistent with Collis et al's (2003) statement that online learning often requires a large amount of self discipline on the part of the learners.

It is noted that when comparing in-class online discussions with in-class oral discussions, the comparison focus is the communication mode. However, when comparing in-class discussions with off-class online discussions, the focus of comparison shifts to the context. During class, learners could not walk away and they are given a reasonable amount of time for posting to an online discussion. In addition, the presence of the instructor is likely to prompt them to engage in online discussion more extensively in-class even though they are not obligated to do so. In contrast, out of class the learners have to deliberately choose to log in to a discussion and sense little immediate pressure to take part. The "off-class" contributions seem to be made on a voluntary basis. Therefore the quality and quantity of discussions depends on not only the communication mode, but also the context.

Although blended learning is considered to combine "the best of both worlds", it can also mix the least effective elements of both worlds if it is not well-designed (Graham, 2005). While in-class online discussion offers the potential for encouraging participation and creating deep learning opportunities in a blended learning environment, making this happen requires good learning design and organisation. Courses that include inclass online discussion as a supplement to oral discussion need to carefully 
integrate this activity into the overall course design, so students see it as integral to the class and not as a disassociated activity.

In this study, all the learners were adults who were highly motivated to participate because the discussions were closed related to their work. This online group showed good participation even though the discussions were not graded. Due to the specific context for this study, generalisation from the findings may be limited. The finding that in-class online discussion is a useful strategy may be context dependent. Therefore, further research is needed to explore the effectiveness or weakness of in-class online discussion for blended learning in broader contexts.

\section{References}

Anderson, T., Rourke, L., Garrison, D. R. \& Archer, W. (2001). Assessing teaching presence in a computer conference context. Journal of Asynchronous Learning Networks, 5(2). http:/ / www.sloan-c.org/publications/jaln/v5n2/v5n2_anderson.asp

Bersin \& Associates (2003). Blended learning: What works? An industry study of the strategy, implementation, and impact of blended learning. Bersin \& Associates.

Bonk, C. J. \& Kim, K. J. (2005). Future directions of blended learning in higher education and workplace learning settings. In C. J. Bonk \& C. R. Graham (Eds.), Handbook of blended learning: Global perspectives, local designs. San Francisco, CA: Pfeiffer Publishing.

Bonk, C. J. \& Graham, C. R. (Eds.) (2005). Handbook of blended learning: Global perspectives, local designs. San Francisco, CA: Pfeiffer Publishing.

Capozzoli, M., McSweeney, L. \& Sinha, D. (1999). Beyond kappa: A review of interrater agreement measures. The Canadian Journal of Statistics, 27(1), 3-23.

Clulow, V. \& Brace-Govan, J. (2001). Learning through bulletin board discussion: A preliminary case analysis of the cognitive dimension. Paper presented at the Moving Online Conference II, September 2-4, 2001, Gold Coast, Australia.

Cohen, J. (1960). A coefficient of agreement for nominal scales. Education and Psychological Measurement, 20, 37-46.

Collis, B., Bruijstens, H. \& Veen van der, J.K. (2003). Course redesign for blended learning: Modern optics for technical professionals. International Journal of Continuing Engineering Education and Lifelong Learning, 13(1/2), 22-38.

Curtis, D. D. \& Lawson, M. J. (2001). Exploring collaborative online learning. Journal of Asynchronous Learning Networks, 5(1), 21-34. http: / / www.sloanc.org/publications/jaln/v5n1/v5n1_curtis.asp

De Wever, B., Schellens, T., Valcke, M. \& Van Keer, H. (2005). Content analysis schemes to analyze transcripts of online asynchronous discussion groups: A review. Computers $\mathcal{E}$ Education. 46, 6-28. 
Dehler, C., \& Parras-Hernandez, L. H. (1998). Using computer-mediated communication $(\mathrm{CMC})$ to promote experiential learning in graduate studies. Educational Technology, 38(3), 52-55.

Dziuban, C., Hartman, J., Juge, F., Moskal, P. \& Sorg, S. (2005). Blended learning enters the mainstream. In C. J. Bonk \& C. R. Graham (Eds.). Handbook of blended learning: Global perspectives, local designs. San Francisco, CA: Pfeiffer Publishing.

Fahy, P. J. (2005). Two methods for assessing critical thinking in computermediated communications (CMC) transcripts. International Journal of Instructional Technology and Distance Education, 2(3). [viewed 2 March 2007] http: / / www.itdl.org/Journal/Mar_05/article02.htm

Fahy, P., Ally, M., Crawford, G., Cookson, P. S., Keller, V. \& Prosser, F. (2000). The development and testing of a tool for analysis of computer mediated conferencing transcripts. Alberta Journal of Educational Research, 46(1), 85-88.

Garrison, D. R., Anderson, T. \& Archer, W. (2001). Critical thinking, cognitive presence, and computer conferencing in distance education. American Journal of Distance Education, 15, 7-23. [viewed 2 Mar 2007, verified 20 June 2007] http: / / communitiesofinquiry.com/documents /CogPres_Final.pdf

Gay, G., Sturgill, A., Martin, W. \& Huttenlocher, D. (1999). Document centered peer collaborations: An exploration of the educational uses of networked communication technologies. Journal of Computer-Mediated Communication, 4(3). [verified 20 Jun 2007] http: / / jcmc.indiana.edu/vol4/issue3/gay.html

Graham, C. R. (2005). Blended learning systems: Definition, current trends, and future directions. In C. J. Bonk \& C. R. Graham (Eds.), Handbook of blended learning: Global perspectives, local designs (pp. 3-21). San Francisco, CA: Pfeiffer Publishing.

Graham, C. R., Allen, S. \& Ure, D. (2003). Blended learning environments: A review of the research literature. Unpublished manuscript, Provo, UT.

Gunawardena, C. N., Lowe, C. A. \& Anderson, T. (1997). Analysis of a global online debate and the development of an interaction analysis model for examining social construction of knowledge in computer conferencing. Journal of Educational Computing Research, 17, 397-431.

Hara, N., Bonk, C. \& Angeli, C. (2000). Content analysis of online discussion in an applied educational psychology course. Instructional Science, 28(2), 115-152.

Harasim, L. (1989). Online education: A new domain. In R. Mason \& A. Kaye (Eds), Mindweave: Communication, computers and distance education (pp. 50-57). Oxford: Pergamon Press.

Harasim, L., Hiltz, S. R., Teles, L. \& Turoff, M. (1995). Learning networks: A field guide to teaching and learning online. Cambridge, Massachusetts: The MIT Press.

Henri, F. (1992). Computer conferencing and content analysis. In A. R. Kaye (Ed.), Collaborative learning through computer conferencing: The Najaden Papers, 115-136. New York: Springer. 
Moore, M. G. (2002). What does research say about the learners using computermediated communication in distance learning? American Journal of Distance Education, 16(2), 65-81.

Morgan, K. R. (2002). Blended learning: A strategic action plan for a new campus. Seminole, FL: University of Central Florida.

Newman, D. R., Webb, B. \& Cochrane, C. (1995). A content analysis method to measure critical thinking in face-to-face and computer supported group learning. Interpersonal Computing and Technology, 3, 56-77. [viewed $2 \mathrm{March}$ 2007] http: / / www.qub.ac.uk/mgt/ papers / methods/contpap.html

Noelle-Neumann, E. (1984). The spiral of silence: Public opinion -- Our social skin. Chicago: University of Chicago.

Oriogun, P. K. (2003). Towards understanding online learning levels of engagement using the SQUAD approach to CMC discourse. Australian Journal of Educational Technology, 19(3), 371-387. http:/ / www.ascilite.org.au/ajet/ ajet19/oriogun.html

Osguthorpe, R. T. \& Graham, C. R. (2003). Blended learning systems: Definitions and directions. Quarterly Review of Distance Education, 4(3), 227-234.

Pena-Shaff, J. B. \& Nicholls, C. (2004). Analyzing student interactions and meaning construction in computer bulletin board discussions. Computers $\mathcal{E}$ Education, 42 , $243-265$.

Prain, V. \& Lyons, L. (2000). Using information and communication technologies in English: An Australian perspective. In A. Goodwyn (Ed.), English in the digital age. London: Cassell Education.

Reynolds, T. \& Greiner, C. (2005). Integrated field experiences in online teacher education: A natural blend? In C. J. Bonk \& C. R. Graham (Eds.). Handbook of blended learning: Global perspectives, local designs. San Francisco, CA: Pfeiffer Publishing.

Ross, B. \& Gage, K. (2005). Global perspectives on blending learning: Insight from WebCT and our customers in higher education. In C. J. Bonk \& C. R. Graham (Eds.). Handbook of blended learning: Global perspectives, local designs. San Francisco, CA: Pfeiffer Publishing.

Rourke, L., Anderson, T., Garrison, D. R. \& Archer, W. (1999). Assessing social presence in asynchronous text-based computer conferencing. Journal of Distance Education, 14, 51-70.

Ruberg, L. F., Moore, D. M. \& Taylor, C. D. (1996). Student participation, interaction, and regulation in a computer-mediated communication environment: A qualitative study. Journal of Educational Computing Research, $14(3), 243-268$.

Sproull, L. \& Kiesler, S. (1991). Connections: New Ways of Working in the Networked Organization. Cambridge, MA: MIT Press. 
Weinberger, A. \& Fischer, F. (2005). A framework to analyze argumentative knowledge construction in computer supported collaborative learning. Computers \& Education, 46(1), 71-95.

Valacich, J., Dennis, A. \& Connolly, T. (1994). Idea generation in computer based groups: A new ending to an old story. Organizational Behavior and Human Decision Processes, 57, 448-467.

Veerman, A. \& Veldhuis-Diermanse, E. (2001). Collaborative learning through computer-mediated communication in academic education. In Euro CSCL 2001 (pp. 625-632). Maastricht: McLuhan institute, University of Maastricht. [verified 20 Jun 2007] http:/ / www.1l.unimaas.nl/euro-cscl/Papers/166.doc

Vrasidas, C. \& McIssac, M.S. (1999). Factors influencing interaction in an online course. American Journal of Distance Education, 13(3), 22-36.

Vygotsky, L. S. (1962). Thought and language. Cambridge: The MIT Press.

Warschauer, M. (1997). Computer-mediated collaborative learning: Theory and practice. Modern Language Journal, 81, 470-481.

An earlier and briefer version of this paper was presented at the ICCE 2006 Conference, and published in its Proceedings: R. Mizoguchi, P.

Dillenbourg \& Z. Zhu (Eds) (2006). Learning by effective utilization of technologies: Facilitating intercultural understanding (pp.149-156). IOS Press. This paper was one of three recipients of ICCE 2006's Best paper Awards.

Wenli Chen PhD (Nanyang Technological University) is an Assistant Professor in Learning Sciences and Technologies Academic Group and a faculty researcher at the Learning Sciences Laboratory, National Institute of Education, Nanyang Technological University.

Chee-Kit Looi PhD (University of Edinburgh) is an Associate Professor in Learning Sciences and Technologies Academic Group, National Institute of Education, Nanyang Technological University. He is also the Head of the Learning Sciences Laboratory.

Correspondence may be addressed to either Dr Wenli Chen or Dr CheeKit Looi, Learning Sciences Laboratory, National Institute of Education, Nanyang Technological University, 1 Nanyang Walk, Singapore 637616 Email wenli.chen@nie.edu.sg, cheekit.looi@nie.edu.sg 